\title{
Existence of Outdoor Reklame Assessed from The Estethics of The Public Space in Teuku Umar Denpasar
}

\author{
I Gusti Bagus Adistanaya ${ }^{1}$ \\ Program Study of Architecture, Faculty of Engineering, Udayana University \\ Faculty of Engineering, Udayana University \\ Denpasar, Bali \\ adistanaya@yahoo.com
}

\begin{abstract}
The rise of trade and service competition affects the emergence of various promotional media whose existence is placed in strategic spaces in urban centers that cause discomfort and decreased quality of the beauty of the city. This study aims to examine the typology of outdoor signage, public perception of the existence of outdoor signage and its influence on the aesthetics of public space. Data collection is done through a qualitative (descriptive) approach. Descriptive qualitative analysis techniques are used to describe and explain certain phenomena using descriptions, explanations and understandings. In this research activity, descriptive qualitative analysis techniques are used to explain the general picture and the results of interviews so that the analysis conducted must be able to produce output in accordance with the goals and objectives set. The results of the analysis show that the advertisement characteristics in the public spaces of Teuku Umar Denpasar street are dominated by commercial outdoor signage. Respondents' perceptions of the existence of outdoor billboards showed (66\%) assessed that billboards had not created city order, $(60 \%)$ assessed that they had not created city beauty, $(80 \%)$ rated size as inappropriate, $(74 \%)$ assessed attractive colors, $(77 \%)$ rate disturbing lighting and (86\%) rate disturbing the building facade as big as. From the results of the analysis, regulations are needed to bring order to reinstall outdoor billboards in order to create order and beauty of the city of Denpasar.
\end{abstract}

Index Terms - outdoor billboards, aesthetics, public space

\section{INTRODUCTION}

City is a spatial unit that accommodates activities of various interests, including those related to the economic, political, social, cultural and environmental sectors. In the era of digitalization that prioritizes the achievement of growth in economic development, the values and practices that are considered potential to generate economic benefits will receive priority for handling and attention. So that among the aspects of urban activities that play an important role in influencing urban growth is the trade and services sector, both carried out by government and non-government parties. 
As is the case in other big cities, in almost every road segment in Denpasar City, trade and service activities are accompanied by the installation of various outdoor billboards. Billboards are a form of visual communication that serves to convey commercial messages. In an effort to promote traded products, this promotional media - its existence - is always placed in a strategic space from the city center, to maximize the information propaganda to be promoted.

The existence of hierarchically organized outdoor billboards can provide multiple benefits for local municipalities. First, billboards are a source of income for local governments. Second, billboards have the potential to beautify the city. Third, billboards are able to provide access to information for the urban community, especially related to things demonstrated in outdoor advertising. One of the strategic places chosen as the location for outdoor advertising is a crossroads [1].

In assessing space as a place for billboard installation, it is inseparable from various determining indicators that need to be considered, including: issues related to licensing from the local government appointed to handle this field, the size of outdoor billboards, access, travel flow, types of advertisements and the harmony of billboards. outdoor space with the surrounding buildings. If the billboards are arranged in a certain diversity or pattern, this will be able to act as an aesthetic forming element in an area or city space. On the other hand, if the billboards are not arranged in a certain pattern, this will have an impact on visual discomfort and reduce the aesthetic quality of an area.

Based on preliminary observations, the installation of billboards in various road segments in Denpasar City, their placement and appearance have not shown added value to the city's aesthetics nor have they characterized an area. The author views that the city of Denpasar needs a regulation that regulates the existence of outdoor billboards, both in the form of advertising arrangements attached to buildings and those that are installed independently of the building. It is hoped that advertising will not only act as a promotional forum for various trade products and services, but also as an element of urban planning and design that is able to synergize with other elements in building the image and beauty of an area.

As a major commercial area in Denpasar City, the Teuku Umar Street Corridor has quite complex trade building functions. The types of products that are traded include cellphones and electronic devices, shoes, building materials, bicycles, and others. In this area also accommodates entertainment venues with the emergence of places for karaoke, and also accommodates tourist accommodation in the form of hotels, and various types of supporting activities in the form of culinary spots. All of these functions make the Teuku Umar Street Corridor one of the densely populated road lanes in Denpasar City.

In accommodating its role as a commercial area, the
Teuku Umar Street Corridor has become a potential home for various forms of outdoor advertising. As is the case with the condition of the installation of billboards in various areas of Denpasar City, the existence of promotional elements in the Teuku Umar Street Corridor does not yet have a structured concept and shape, so that it can provide added value to the image development and the beauty of the city area. This condition has motivated the implementation of research aimed at examining the typology of outdoor billboards that occur in the Teuku Umar Corridor, examining people's perceptions of the existence of outdoor billboards and their impact on the aesthetics of urban space, especially the Teuku Umar Street Corridor. It is hoped that the results obtained through the implementation of this study will be able to act as a guideline for policy makers in regulating outdoor advertising media.

\section{RESEARCH METHODS}

In accordance with the research objectives, this study applies qualitative research methods. Data collection was carried out by field observation, photographic documentation, and interviews. Data analysis was carried out using a descriptive qualitative approach, both in analyzing the typology of outdoor billboards and the views of the community regarding the contribution of outdoor billboards to the aesthetics of urban space. The research sample was taken using incidental sampling technique, namely the research sample that was directly found in the field. This technique is applied in the selection of outdoor billboards in the Teuku Umar Street Corridor and in the selection of respondents. The number of respondents interviewed was 35 people, who came from visitors and workers who were active along the Teuku Umar Street Corridor.

The choice of Jalan Teuku Umar is based on the function of the road, the function of the area and the development of outdoor billboards that exist in the corridor of Jalan Teuku Umar which is quite numerous and varied. The choice of research location was done purposively with the consideration that the location is very strategic.

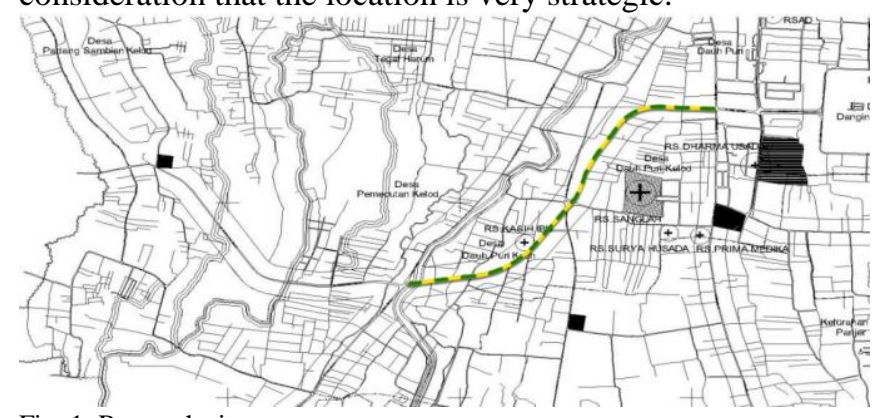

Fig. 1. Research sites

Source: Bappeda Denpasar City, 2015

\section{RESUlt AND ANALISYS}

\section{A. Literature Review}

Literature review is a bridge for researchers to get a theoretical foundation as a guideline for the source of 
hypotheses, this bridge actually takes the form of knowledge about research conducted by other researchers in the research area. This knowledge is not only in the form of an understanding of these studies, but also of the interrelations that are formed between these studies. As is known, a study does not just appear, but it always tries to solve or answer problems left by previous research.

Aesthetics in general is always related to the shape and quality of a material. Material form is a physical form that can be captured by the eye. The visual aesthetic quality is the result of a meeting between the physical elements of the landscape and the psychological processes of the observer. Quoted from Pramono [1], in the mapping of outdoor billboards technically, the regulated elements are based on the aesthetic issues of outdoor billboards related to the quality of the city environment and refer to the needs of the community for their own environment. Technical elements that need to be arranged in this case as mentioned above include the form, number, location, area, lighting and placement [1]. The aesthetic elements are:

1. The form of outdoor billboards

Design formation that can reflect the type of design affects the aesthetics of an object. According to its shape or type, outdoor billboards are divided into 13 types, namely headband outdoor billboards, buggy outdoor billboards, outdoor display billboards, film or slide outdoor billboards, outdoor sound billboards, outdoor air billboards, outdoor walking billboards outdoor billboards, flyers or brochures, outdoor billboards, outdoor billboards, megatrons, videotrons, large electronic displays (LED), video and dynamic walls, banners or banners or banners, outdoor billboards, posters or stickers. Of course, all forms of outdoor advertising are judged by their unique, simplicity, and easy to remember.

\section{Intensity}

Based on observations, the intensity of outdoor advertising varies. Design will be of high value if you pay attention to design principles, one of which is the scale in the form of intensity and others. Pramono [1] states that the resource aspect of visual diversity (function in number) can affect the visual observer so that it affects the aesthetic value. Landscape components that have the appropriate and harmonious number, diversity, and pattern will have a high aesthetic value. Among them are the appearance of outdoor billboards, the suitability of the placement of outdoor billboards and the suitability of one media with another.

3. Surrounding environment

Meliawati [2] states that the dominant landscape elements in the aesthetic quality of outdoor advertising are vegetation, buildings, pavement, water and sky. The elements that are quite prominent are buildings (buildings) and vegetation. Furthermore, Meliawati said that the elements of the sky do not have a significant correlation with aesthetic qualities; whereas for pavement and water, the effect is not prominent if the visual scale of the element is not large according to the size placement with the environment.

\section{Lighting}

Based on research by Nurmasari [3], the effect of lighting can affect the aesthetics of an object. The distribution of lighting is usually more about night lighting. Because the difference in lighting sources is used as treatment of aesthetic factors on outdoor advertising.

In a simple definition public space is an open space that is outside a building, including: roads, fields, city parks, etc. [4]. Public spaces can accommodate various community activities individually or in groups.

Rob Krier [3] states that public space is the space formed between building masses [3]. In line with that, Hakim [3] also explained that public space has a function as a means of human mobility to move from one building to another or from one place to another [3].

Hakim [3] explained that the public space has 2 main functions, namely: a social function and an ecological function. In its function as a social function, public space is a forum for various activities, including: playing, sports, communication, harmony, environmental beauty, barriers between building masses, and others. And as an ecological function of public space, it plays a role as air freshener, rainwater absorption, ecosystem preserver, architectural softener, and others. If public space is used according to its function, this space can also be part of the aesthetic element of the city space. This can be obtained from elements and activities in the public space itself.

From several theoretical studies such as in the discussion above, the arrangement of outdoor billboards produces several elements and aspects that must be considered in seeing the aesthetics of outdoor billboards in the corridor of Teuku Umar street, Denpasar City. These elements and aspects are its shape, appearance, beauty, suitability of placement, suitability of one medium to another, suitability of size placement with its environment, lighting at night and not disturbing the freedom of time and activities that occur in the public space.

\section{B. Characteristics and Typology of Outdoor Advertising}

The form of outdoor advertising can be divided into various classifications. In general, this classification is carried out based on the following matters, namely message content, material, information properties and technical installation. The following describes the categorization of outdoor billboards found along the Teuku Umar Street Corridor.

1. Based on the content of the message, advertisement media are divided into [3]:

a. Commercial media, regarding advertisement media that provides information on goods or services for trade purposes (private sign).

b. Non-commercial advertisement media are advertisement media that contain information on services to the public (public sign). 
2. Based on the materials and time periods used, advertisement media are divided into [3]:

a. Permanent advertising media. Generally, this media is placed or made on its own foundation, put into the ground, installed or drawn on a permanent structure. Most of these types of advertising media are allowed to be installed.

b. Temporary advertising media. This advertisement media is used at a certain time only when there is an event / show and the like, and after that it is no longer used. This type of advertising media has the characteristic of being easy to move or dismantle without being made of expensive materials.

3. Based on the nature of the delivery of information, consisting of [3]:

a. Direct advertising media. This media is related to activities in a building or environment where the advertisement media is placed, such as advertising media that shows the identity of a business or building.

b. Advertising media that are indirect. This type of advertising media contains messages that do not have a direct relationship with activities in the building or the environment where the advertisement media is located.

4. Technically the installation, advertising media is divided into [3]:

a. Media advertising that stands alone (free standing signs), has two forms, namely:

- Advertising media with pole signs. This advertising media is supported by poles, sometimes more than one, separated from the ground by the air and separated from other buildings and structures.

- Advertising media located on the ground (ground sign). The basis of this advertisement media is located on the ground or covered by soil and separated from other buildings or structures.

b. Advertising media on the roof of the building (roof signs) consisting of:

- Advertising media that is not attached to the roof. This advertisement media is built on the roof of the building, supported by the roof structure and is high above the roof.

- Advertising media that attaches to the roof. The advertisement media that is attached to the roof is characterized by the absence of part of the advertisement media that exceeds the height of the roof and is installed in parallel no more than $21 \mathrm{~cm}$.

c. Advertising media from tents and awnings (canopy and awning sigs) which include:

- Advertising media on tents and permanent awnings.

- Publicly visible advertisements on tents and awnings.

a. Projected sig n. This advertisement media is placed on the building or building wall in such a way as to face the flow of vehicles and a distance of not more than $15 \mathrm{~cm}$ from the building wall and is installed perpendicular to the building.

b. Advertising media that is placed on the wall (wall signs). Advertising media that fall into this category are advertisement media installed parallel within a maximum distance of $15 \mathrm{~cm}$ from the building wall, advertisement media painted on the surface of the wall or other building structures.

c. Hanging advertising media (suspended signs). This advertisement media is hung at the bottom of the horizontal plane (ceiling) on the building foyer. Generally, this advertisement media is smaller than a signboard or address to notify pedestrians who cannot see the larger media advertisements that are placed on the wall above the foyer at the front of the building.

d. Advertising media above the entrance and exit of the building (marquee signs). This advertisement media is placed on a building structure such as a roof above the entrance and exit of the building.

Advertising media on windows or doors (window / door signs). Advertising media of this type can be in the form of pictures, symbols or a combination of both designed to provide information about an activity, business, commodity, event, trade or trade or service temperature that is placed on a glass window or door and is visible from the outside.

\section{Analysis of Advertising Characteristics}

Based on direct observations in the field, the authors constructed the characteristics of all outdoor billboards found along the Teuku Umar Corridor. These characteristics are built on the type or salient features of existing outdoor billboards. If it is related to the advertisement typology previously described, the most common category found is outdoor advertising based on the message content and the technicality of its installation. In accordance with the function of the Jalan Teuku Umar Corridor as a trade and service route in Denpasar City, the existence of commercial advertisements is far more prominent than non-commercial billboards. As previously stated, the characteristics of commercial billboards as a promotional tool, try to make the object advertised the center of attention and show the difference in its installation compared to non-commercial advertising media.

Meanwhile, when viewed from the technical aspect of its installation, commercial billboards always use bright lighting, large size, sturdy construction and placement at points that become the concentration of many people. Meanwhile, non-commercial billboards tend to look passive, from their small size and shape, the location points are also less strategic and sometimes without lighting. This condition goes hand in hand with the area's characteristic as a business center and trade in goods and / or services in Denpasar City. The installation of commercial billboards in this area implies a relatively high cost, compared to noncommercial billboards which are not subject to a levy tax, 
although sometimes the content is very useful for the community.

D. Outdoor Billboards and Space Aesthetics in the Corridor of Jalan Teuku Umar Denpasar

The discussion in this section includes an assessment of the impact of the existence of outdoor billboards on the spatial aesthetics of the Jalan Teuku Umar Corridor, Denpasar. This study was built based on the perceptions of a group of respondents who were interviewed at the research data collection stage. As for the aspects that are seen as determinants of the aesthetics of the area include: the principle of obedience to the rules governing the existence of billboards in the spatial structure of the city; billboard size; billboard color; billboard lighting; linkage of advertisements to the formation of building facades; and the correlation between billboards and the beauty of the corridor space as a whole.

1. Advertisement and the principle of compliance with applicable regulations

The existence of outdoor billboards in the Teuku Umar Street Corridor in Denpasar City is regulated in Law No. 26 of 2007 concerning the National Spatial Planning (RTRW), Regional Regulation No. 16 of 2009 concerning the Bali Province Spatial Planning (RTRW), Regional Regulation No. 27 of 2011 concerning the Regional Spatial Plan (RTRW) of Denpasar City, Decree No. 188.45 / 568 / HK / 2014 Concerning the Stipulation of the Spread Pattern of Advertising and Placement of Billboard Points in Denpasar City, Mayor Regulation No. 3 of 2014 concerning the Distribution of Billboards in the City of Denpasar.

It is hoped that the enforcement of the aforementioned regulations will create order in the use of urban spaces. In reality, however, technical dynamics and methods of promotion and delivery of information have developed at such a rapid pace, far beyond the capacity of existing regulations to regulate them. So that often the rules are not relevant to be implemented in the field. This condition has the potential to cause practices that are not in accordance with regulations that are no longer relevant to be applied. In this situation, local governments cannot take decisive action either, because the measuring instrument is no longer suitable. In the end, chaos arises in controlling the use of urban spaces and in regulating the impact of space utilization on the quality of urban space, including the aesthetic aspects of the city.

Regarding the arrangement for the installation of outdoor billboards, especially in the Teuku Umar Street Corridor, Denpasar, the community hopes that the government can be more flexible in dealing with growing problems, so that the relevance of the rules can be ratified efficiently and cases that occur can be responsively mediated. and sustainable. The regional government is also expected to be more sensitive to the people who directly feel the impact of a policy in order to develop the principle of obedience which will influence the creation of order in the city.

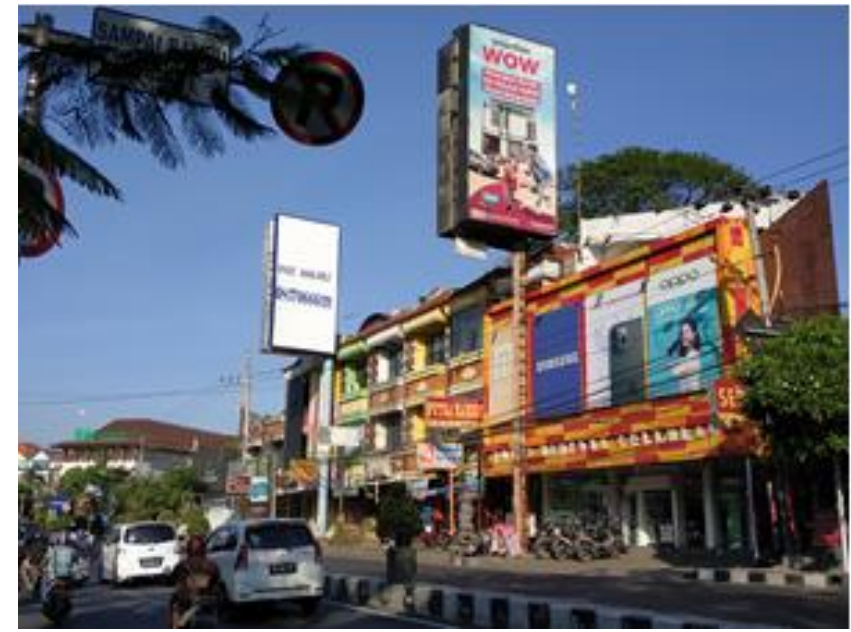

Fig. 2. Advertisements that do not comply with the rules Source: I Gusti Bagus Adistanaya, 2019

From Figures 2 and 3 in the picture above 35 respondents who were interviewed regarding the issue of installing outdoor billboards and the principle of obedience to the relevant regulations that apply, 23 people $(66 \%)$ of respondents saw that the current conditions in the field did not support the development of order in the city. Twelve (12) other respondents (34\%) said things that were against or were still creating urban order. Figure 2 represents billboards that do not comply with government regulations due to being too close to pedestrian areas and sticking to buildings that are very dangerous for pedestrians and residents in the building.

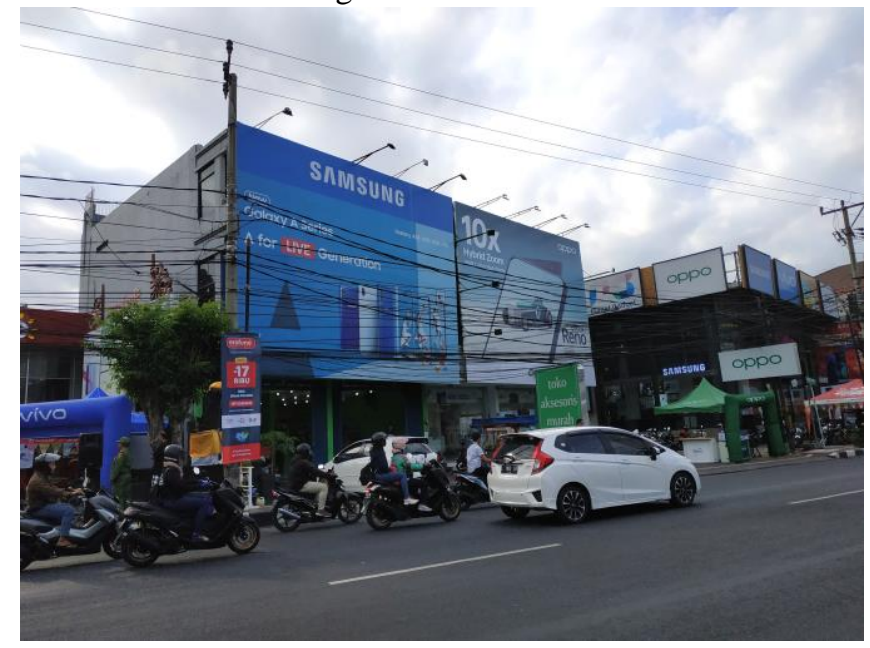

Fig. 3. The size of the billboard is too big

Source: I Gusti Bagus Adistanaya, 2019

\section{The size of the billboard}

The respondent's assessment of the suitability of the billboard size can be described as follows. Twenty-eight (28) respondents $(80 \%)$ agreed that the size of advertisements does not support the creation of aesthetics in cities and 7 respondents (20\%) said otherwise. The number of respondents assessed that the size of the billboards installed was inappropriate because the larger the size of the billboards, the less he paid or the lower the value of the beauty of the city. On the other hand, respondents who rated 
'appropriate' thought that the larger the size of the billboard, the more information was conveyed regardless of the beauty of the city (Figure 3 ).

3. Color of the billboard

Most of the respondents (26 respondents (74\%) considered the use of colors on billboards installed in public spaces (74\%). Meanwhile, 9 respondents $(26 \%)$ considered it unattractive. The appearance of colorful billboards is seen as building a chaotic and visually unpleasant impression. This in turn will reduce the level of beauty of the spaces in a city corridor (Figure 4).

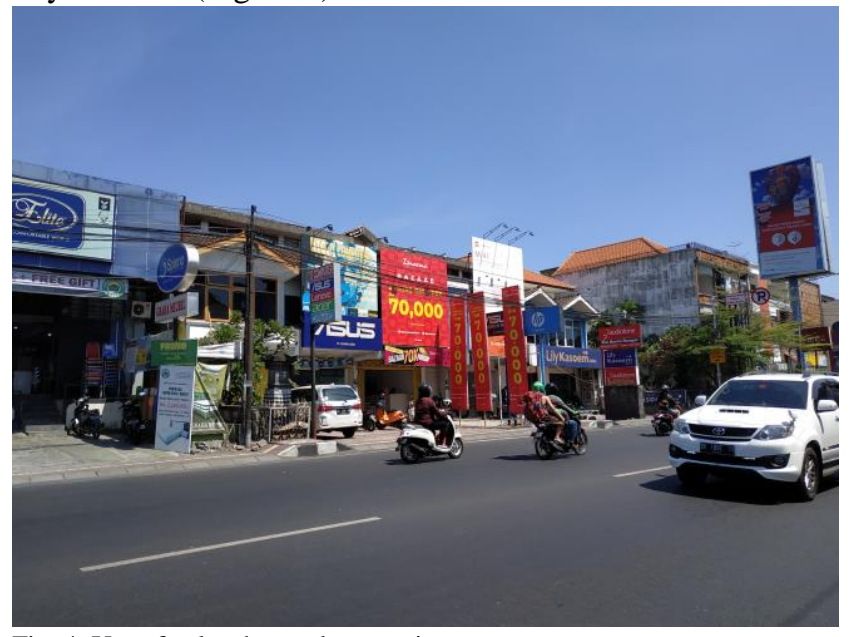

Fig. 4. Use of color that grabs attention Source: I Gusti Bagus Adistanaya, 2019

\section{Types of lighting}

27 respondents (77\%) considered the lighting of billboards in the corridor of Teuku Umar Street. Then 8 respondents (23\%) said they did not disturb. The number of respondents assessed that the lighting on billboards was disturbing because of the background of the reflection of light emitted by billboards which often dazzled the eyes of the beholder, especially those that occurred at night. Besides that, it can be seen in Figures 5 and 6 that the lighting of the videotron media installed at the Simpang Six Jalan Teuku Umar is also very dazzling and endangers motorists. Meanwhile, respondents who thought they were not disturbing said that the lighting on the billboards helped illuminate the streets around them, so that the city government no longer needed to install street lighting.

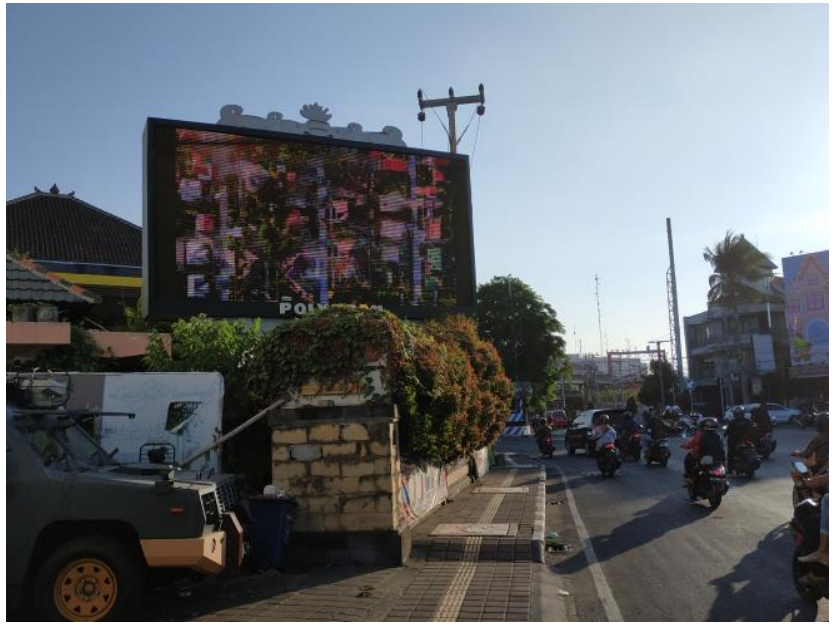

Fig. 5. Lighting is distracting

Source: I Gusti Bagus Adistanaya, 2019

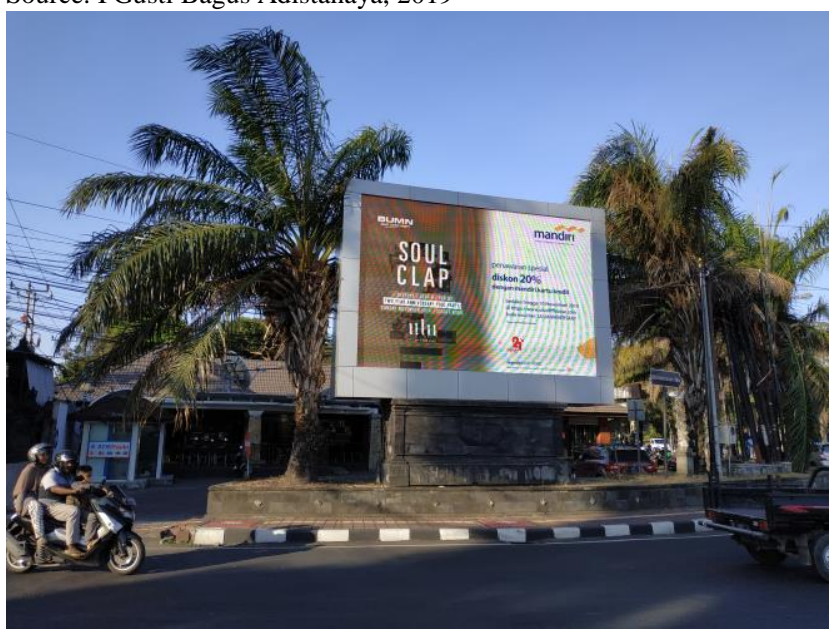

Fig. 6. Lighting is distracting

Source: I Gusti Bagus Adistanaya, 2019

5. Building facades

The following is a respondent's assessment of the effect of installing outdoor billboards on building facades, considering the advertisements attached to shopping buildings in the Teuku Umar Street Corridor. Thirty respondents $(86 \%)$ viewed that the current practice of installing billboards does not reflect the appearance of a cultural and traditional building facade. This is because the billboards attached to the shopping buildings cover most of the buildings so that the Balinese characteristics or styles on the buildings are not visible (Figures 7 and 8). Meanwhile, 5 respondents $(14 \%)$ considered that the effect of billboards on the building facade did not have a negative impact on the beauty of the building's facade. This is because most of the building structures in the Teuku Umar Street Corridor function as shops that do not have dominant decorative styles. 


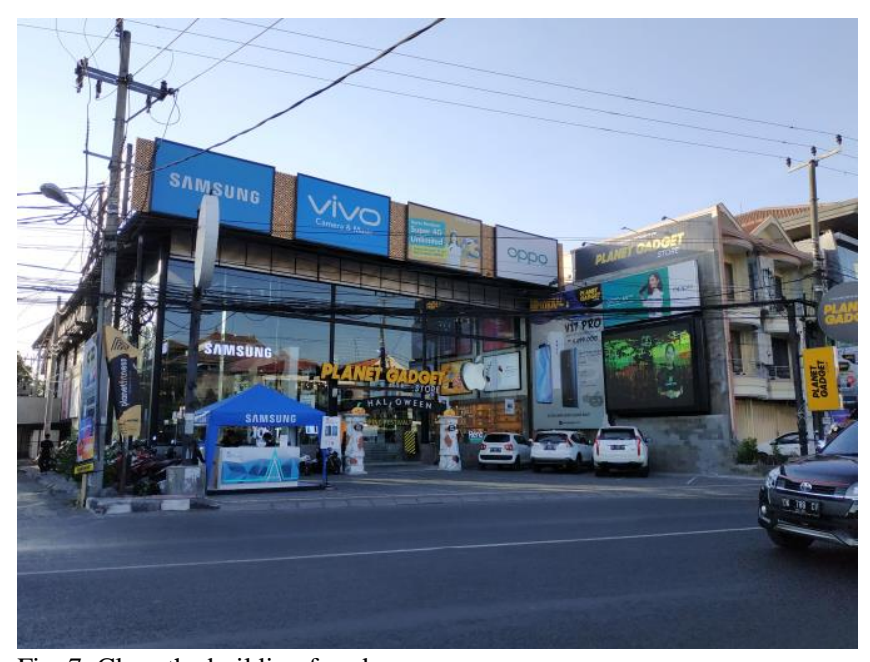

Fig. 7. Close the building facade

Source: I Gusti Bagus Adistanaya, 2019

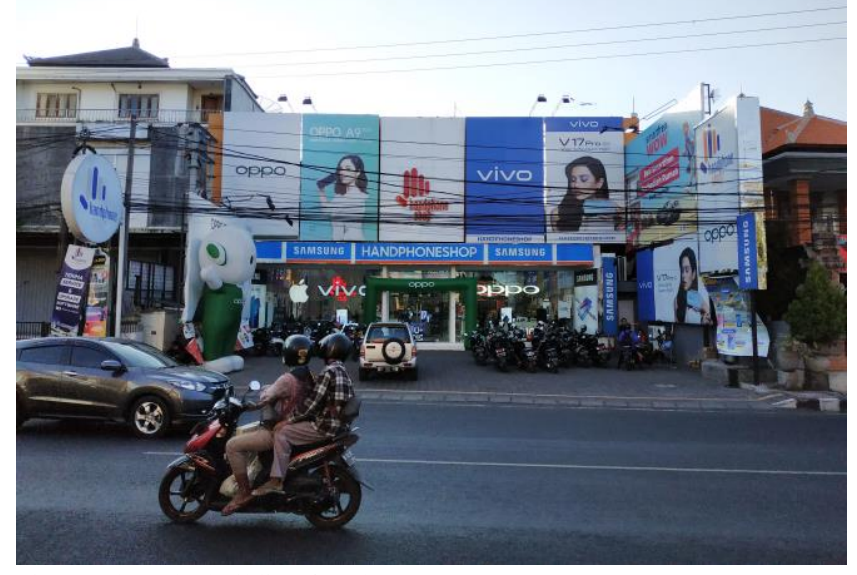

Fig. 8. Close the building facade

Source: I Gusti Bagus Adistanaya, 2019

6. Installation of billboards and criteria for urban beauty (city aesthetics)

It is hoped that the installation of outdoor billboards can be a supporting factor in adding to the beauty of urban space. This then becomes the reason why the Denpasar City Government mandates the installation of billboards to become icons that can help the beauty of the City of Denpasar. In this regard, based on the results of an opinion survey through interviews with 35 respondents, it was found that 21 of them $(60 \%)$ said that the current practice of installing outdoor billboards does not entirely support the creation of a beautiful city. And 14 respondents (40\%) said that they have gone hand in hand with efforts to create urban aesthetics.

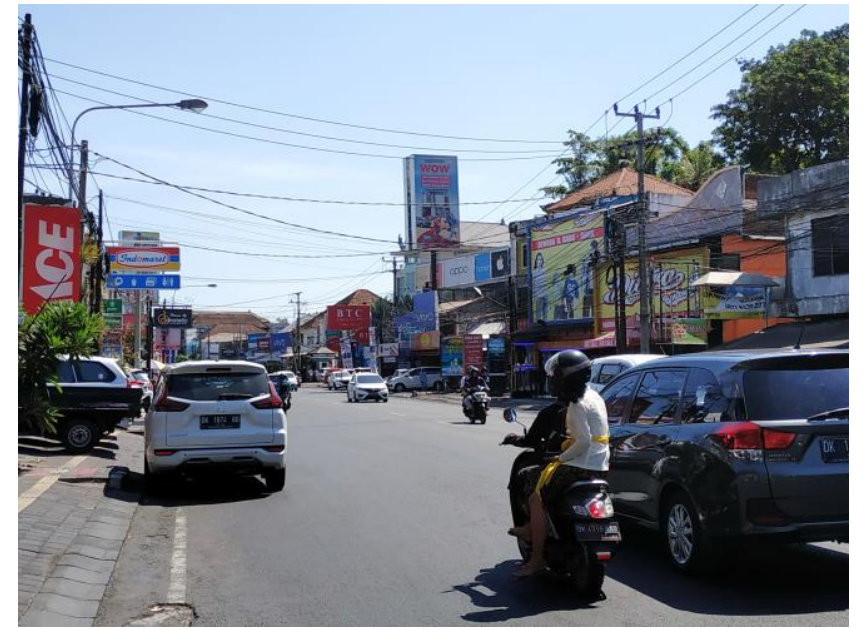

Fig. 9. The overlapping billboards create chaos

Source: I Gusti Bagus Adistanaya, 2019

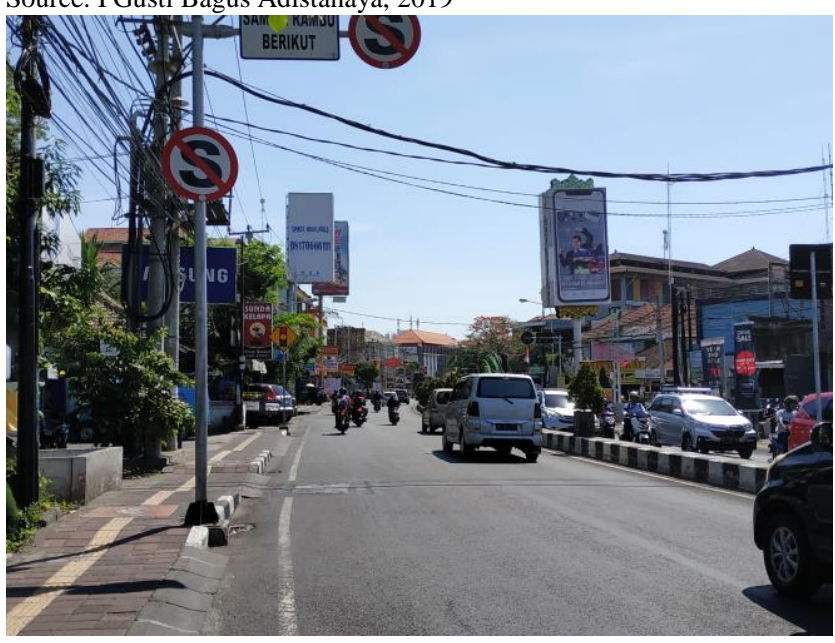

Fig. 9. The overlapping billboards create chaos

Source: I Gusti Bagus Adistanaya, 2019

From the results of the studies and interviews with the 35 respondents above, it can be assessed that the existence of billboards on the Teuku Umar street, Denpasar, has not been able to add visual quality in achieving the beauty of the city. Visual quality is one of the most important elements in shaping a city image. A good visual city quality will provide aesthetic satisfaction for its residents. It can be said, that the visual chaos of the city will also add to the stress burden on its residents. Billboards in the city center, as one of the visual elements of the city, also have the potential to create or add to the visual chaos of the city, if not arranged properly.

In this research, it is often found that apart from its function as a conveyor of information, the design and placement of billboards on Jalan Teuku Umar Denpasar has the potential to cause visual chaos. This visual chaos results in a decrease in the visual quality of outer-city spaces.

\section{E. The Layout of Outdoor Billboards and the Beauty of Inner City Corridors}

Moving on from the view that the existence of outdoor billboards affects the beauty of the city, this study posits that the placement of billboards is the main aspect that determines the contribution of advertisements in building 
the beauty of space in the Teuku Umar Street Corridor. The following section describes several things that can be taken into consideration in determining the layout of outdoor billboards for the Jalan Teuku Umar Denpasar Corridor, namely:

a. Placement that takes into account the visilibility (visibility)

Visilibility in the installation of billboards is very necessary. This is especially important to achieve the intended message delivery. Visilibility is influenced by factors of location, pole placement, lighting, reflected paint and so on. Visilibility considerations aim to determine the layout of the billboard so that the intent and purpose of the billboard is conveyed to the public who reads it. But the question here is how the visibility of the various billboards is arranged without disturbing one billboard to another.

b. Legibility aspects (legibility and clarity of information)

The legibility of information is closely related to the type and size of letters, spacing of letters, basic colors used, font colors and so on so that motorists can still read them. So this aspect of ligibility will have a direct relationship with the visibility aspect described above.

c. Placement that takes into account the balance aspect

The balance in outdoor advertising can be measured from the layout of the billboards, size, color and information to be conveyed by the number of billboards that are in a certain area. Balance can also be obtained from the perception of society who sees some of the target objects by taking into account beauty, order and order. This aspect is also directly related to the other two aspects described above.

d. Placement that takes into account the aspect of harmony with the building

This is important to emphasize because the Denpasar City Government has enforced a regulation so that every building uses Balinese Langgam or Balinese architecture. So any installation of outdoor billboards should not cover the entire facade of the building and still reflect local culture. The building facade is a part of a building that is usually used as a container in which local components, especially decorations and other local decorative elements are installed. If the Regional Government wants this feature to be displayed, then its existence must not be covered by outdoor billboards. So the placement of promotional elements should not only think about the aspects of visibility, legibility, balance, but also pay attention to the harmony with the image of the city that the Regional Government wants to build.

\section{CONCLUSION}

After doing some analysis in the research to be able to find out the existence of outdoor billboards in the Teuku Umar Street Corridor, it can be concluded as follows:

The existence of outdoor billboards found in Jalan Teuku Umar Corridor, Denpasar is dominated by commercial billboards. In line with this condition, it can be seen from its placement which chooses a strategic place, its large shape, is equipped with bright lighting and its large size. This condition is very different from non-commercial outdoor billboards which choose a place that is not always strategic, small in size and shape and sometimes without lighting.

Respondents' perceptions of the existence of outdoor billboards in the Jalan Teuku Umar Corridor in Denpasar, most of the respondents considered that the billboards had not shown the principle of obedience to the rules that contributed to the creation of urban order $(66 \%)$, had not contributed and added value to the idea of creating beauty cities $(60 \%)$, the size of billboards that do not meet the rules $(80 \%)$, the use of colors that attract attention $(74 \%)$, the use of technical lighting that tends to disturb (77\%), and the covering of building facades thus eliminating the cultural characteristics possessed by various buildings in the Teuku Umar Street Corridor (86\%).

The need for regulations to re-order the installation of outdoor billboards in commercial corridors, so that their existence can add value to the creation of beautiful spaces in Denpasar City.

\section{REFERENCES}

[1] Pramono, E. J. (2006). Persepsi Masyarakat Terhadap Keberadaan Reklame dan Aspek Legal Hukumnya di Jalan Slamet Riyadi Kota Surakarta. Tesis. Semarang: Program Pascasarjana Magister Pembangunan Wilayah dan Kota Universitas Diponegoro.

[2] Dharmawan, E. (2003). Teori Dan Implementasi Perancangan Kota.

[3] Rustiadi, et. al. (1998). Analysis of Land Use Changes in City Suburbs (A Case Study on Some Subdistricts of Bekasi Area of West Java Indonesia). Journal of Rural Planning Assosiation, Vol. 18, No.1.

[4] Carr, S. et. al. (1992). Public Space. Cambridge: Cambridge University Press 